\title{
Analysis of the World Top 1000 Corporations R\&D Investment in 2014: With Focus on those Chinese Corporations
}

\author{
Michael H. Wang \\ Industrial Engineering, MAME Department, University of Windsor, \\ 401 Sunset Avenues, Windsor, Ontario N9B 3P4, CANADA \\ E-mail: wang5@uwindsor.ca
}

\begin{abstract}
Each year, the European Union's (EU) Economics of Industrial Research \& Innovation (IRI) project group will publish a report entitled "R\&D Scoreboard" which summarizes the world top 1,500 to 2,500 corporations (number varies from year to year) $R \& D$ investment in the previous year. In this paper, the author will extract the top 1000 corporations from this EU 2015 report, then analyze and compare the Chinese corporations' performance versus the rest of the pool. By comparing the investment in different sectors, we found that the Chinese corporations' primary R\&D investment, similar to other regions, were in the construction, IT industry, transportation, and energy sectors. However, different from other regions, Chinese $R \& D$ investment in the pharmaceuticals and biotechnology is significantly less than the rest of the world. Our next step is to compare the annual profit margin with the R\&D investment percentages of these Chinese corporations. The objective is to verify whether the Chinese corporations will stick to the sustainable strategy of continuously increasing in R\&D investment, regardless of the short-term revenue fluctuations.
\end{abstract}

Keywords- R\&D Investment; Industrial Sectors

\section{INTRODUCTION}

The Economics of Industrial Research \& Innovation (IRI) is a project conducted by the Directorate on Growth and Innovation, which is one of the institutes of the European Commission's joint research centers. Each year, IRI will publish an annual scoreboard report on the world's top 1000 to 2500 corporations' R\&D investment in the previous year.
The number of corporations reported increases from 500 in the first year of 2004 to 2,500 in the latest report in 2015 .

In this paper, we analyzed the scoreboard published in 2015 [1] and focus on the top 1000 corporations, rather than the entire list of 2,500 corporations. The main reason was based on the fact that the total R\&D investment for the top 1,000 and all 2,500 corporations are $€ 552.7$ billion and $€ 607.2$ billion respectively. By analyzing the top 1000 corporations $(40 \%$ of the 2,500), we greatly reduced the number of companies, yet we still covered $91 \%$ of the total R\&D investment.

Among these top 1000 corporations, Table I below shows the top 20 world corporations and their rank in the previous year, their geographical region, and their 2014 R\&D investment. Notice that the only Chinese corporation (HUAWEI) advanced from 26 in the previous year to 15 in 2014. Other notable citations by the IRI report include:

- In 2014, the top 2,500 companies increased their R\&D investment by $6.8 \%$, while revenues continued to grow at a significant lower rate of $2.2 \%$.

- EU companies show R\&D investment growth rate of $3.3 \%$; US companies show a stronger growth rate $8.1 \%$. The Chinese companies, 3rd largest region by number of companies in 2014 , increase the R\&D investment by $23.6 \%$.

- Companies in the ICT (Information and Communications Technology), Pharmaceuticals and Automobiles sectors continue to dominate the top 10 places in the world ranking.

TABLE I. WORLD TOP 20 CORPORATIONS IN 2014 R\&D INVESTMENT (SOURCE: IRI 2015 SCOREBOARD)

\begin{tabular}{|c|c|c|c|c|c|}
\hline Rank & $\begin{array}{c}\text { Rank } \\
\mathbf{2 0 1 3}\end{array}$ & Company & Region & Sector & $\begin{array}{c}\text { R\&D 2014 } \\
\boldsymbol{\epsilon} \text { millions }\end{array}$ \\
\hline $\mathbf{1}$ & 1 & VOLKSWAGEN & Germany & Automobiles \& Parts & $13,120.0$ \\
\hline $\mathbf{2}$ & 2 & SAMSUNG & S. Korea & Electronic \& Electrical Equipment & $12,187.0$ \\
\hline $\mathbf{3}$ & 3 & MICROSOFT & US & Software \& Computer Services & $9,921.7$ \\
\hline $\mathbf{4}$ & 4 & INTEL & US & Technology Hardware \& Equipment & $9,502.5$ \\
\hline $\mathbf{5}$ & 5 & NOVARTIS & Switzerland & Pharmaceuticals \& Biotechnology & $8,217.6$ \\
\hline $\mathbf{6}$ & 9 & GOOGLE & US & Software \& Computer Services & $8,098.2$ \\
\hline $\mathbf{7}$ & 6 & ROCHE & Switzerland & Pharmaceuticals \& Biotechnology & $7,422.1$ \\
\hline $\mathbf{8}$ & 8 & JOHNSON\& JOHNSON & US & Pharmaceuticals \& Biotechnology & $6,996.1$ \\
\hline $\mathbf{9}$ & 7 & TOYOTA & Japan & Automobiles \& Parts & $6,858.4$ \\
\hline $\mathbf{1 0}$ & 15 & PFIZER & US & Pharmaceuticals \& Biotechnology & $6,844.6$ \\
\hline
\end{tabular}


TABLE I. WORLD TOP 20 CORPORATIONS IN 2014 R\&D INVESTMENT (SOURCE: IRI 2015 SCOREBOARD) (continued)

\begin{tabular}{|l|l|c|c|c|c|}
\hline $\mathbf{1 1}$ & 11 & GENERAL MOTORS & US & Automobiles \& Parts & $6,095.0$ \\
\hline $\mathbf{1 2}$ & 12 & MERCK US & US & Pharmaceuticals \& Biotechnology & $6,056.3$ \\
\hline $\mathbf{1 3}$ & 17 & FORD & US & Automobiles \& Parts & $5,683.2$ \\
\hline $\mathbf{1 4}$ & 10 & DAIMLER & Germany & Automobiles \& Parts & $5,650.0$ \\
\hline $\mathbf{1 5}$ & 26 & HUAWEI & China & Financial Services & $5,441.2$ \\
\hline $\mathbf{1 6}$ & 18 & CISCO SYSTEMS & US & Technology Hardware \& Equipment & $5,112.4$ \\
\hline $\mathbf{1 7}$ & 16 & ROBERT BOSCH & Germany & Automobiles \& Parts & $5,042.0$ \\
\hline $\mathbf{1 8}$ & 35 & APPLE & US & Technology Hardware \& Equipment & $4,975.7$ \\
\hline $\mathbf{1 9}$ & 14 & SANOFI & France & Pharmaceuticals \& Biotechnology & $4,812.0$ \\
\hline $\mathbf{2 0}$ & 20 & HONDA & Japan & Automobiles \& Parts & $4,576.6$ \\
\hline
\end{tabular}

II ANALYSIS OF THE TOP 1000 COMPANIES BY THE REGION AND BY THE SECTOR

In TABLE II, we regroup the 1000 companies according to their geographical regions and the top 15 regions are presented. China and China-Taiwan combined will rank the $3^{\text {rd }}$, still falling behind the USA and Japan. We should also pay attention to the fact that the USA accounts for roughly $40 \%$ of the world total R\&D investment and the great China area accounts for only $7 \%(5.16 \%$ plus $1.73 \%)$.

TABLE II. WORLD TOP 15 REGIONS IN 2014 R\&D INVESTMENT (SOURCE: IRI 2015 SCOREBOARD)

\begin{tabular}{|c|c|c|c|}
\hline Rank & Region & $\begin{array}{c}\text { Number of Companies } \\
\text { within the 1000 List }\end{array}$ & $\begin{array}{c}\text { Total R\&D 2014 } \\
(\boldsymbol{\epsilon} \text { millions) }\end{array}$ \\
\hline 1 & USA & $\mathbf{3 3 4}(33.40 \%)$ & $\mathbf{2 1 3 , 6 9 7 . 5}(38.66 \%)$ \\
\hline 2 & Japan & $\mathbf{1 5 9}(15.90 \%)$ & $\mathbf{7 9 , 1 5 5 . 1}(14.32 \%)$ \\
\hline 3 & China & $\mathbf{8 1}(8.10 \%)$ & $\mathbf{2 8 , 5 4 9 . 7}(5.16 \%)$ \\
\hline 4 & Germany & $\mathbf{7 0}(7.00 \%)$ & $\mathbf{6 0 , 2 3 1 . 7}(10.90 \%)$ \\
\hline 5 & UK & $\mathbf{5 4}(5.40 \%)$ & $\mathbf{2 2 , 6 8 5 . 7}(4.10 \%)$ \\
\hline 6 & France & $\mathbf{4 9}(4.90 \%)$ & $\mathbf{2 6 , 9 6 1 . 2}(4.88 \%)$ \\
\hline 7 & China-Taiwan & $\mathbf{3 3}(3.30 \%)$ & $\mathbf{9 , 5 7 9 . 6}(1.73 \%)$ \\
\hline 8 & Switzerland & $\mathbf{2 9}(2.90 \%)$ & $\mathbf{2 3 , 8 3 5 . 8}(4.31 \%)$ \\
\hline 9 & South Korea & $\mathbf{2 3}(2.30 \%)$ & $\mathbf{2 1 , 8 3 0 . 9}(3.95 \%)$ \\
\hline 10 & Netherland & $\mathbf{2 2}(2.20 \%)$ & $\mathbf{1 6 , 2 7 5 . 4}(2.94 \%)$ \\
\hline 11 & Ireland & $\mathbf{1 6}(1.60 \%)$ & $\mathbf{6 , 1 6 6 . 6}(1.12 \%)$ \\
\hline 12 & Italy & $\mathbf{1 4}(1.40 \%)$ & $\mathbf{4 , 6 5 7 . 1}(0.84 \%)$ \\
\hline 12 & Sweden & $\mathbf{1 4}(1.40 \%)$ & $\mathbf{8 , 2 8 8 . 5}(1.50 \%)$ \\
\hline 14 & Spain & $\mathbf{1 2}(1.20 \%)$ & $\mathbf{4 , 1 7 8 . 9}(0.76 \%)$ \\
\hline 15 & Canada & $\mathbf{1 0}(1.00 \%)$ & $\mathbf{3 , 5 3 1 . 1}(0.64 \%)$ \\
\hline 15 & Denmark & $\mathbf{1 0}(1.00 \%)$ & $\mathbf{3 , 3 4 2 . 6}(0.60 \%)$ \\
\hline
\end{tabular}

This gap between the USA and the Chinese corporate $R \& D$ investment will be further expanded when considering the total sales and revenues. For the Chinese corporations, the calculation of the $R \& D$ investment as a percentage of their sales and revenues usually has a much larger denominator, i.e., Chinese companies normally have much higher sales and revenues, both in terms of domestic and international markets.

In TABLE III, we showed the number of companies according to the same sector classification scheme by the IRI. The information revealed by the Table confirmed the IRI opinion that "Companies in the ICT (Information and Communications Technology), Pharmaceuticals and Automobiles sectors continue to dominate the top places in the world ranking." Specifically, the "Pharmaceuticals \& Biotechnology' sector weighs approximately $18.55 \%$ of the total world R\&D investment, which is the highest sector. 
TABLE III.

WORLD TOP 10 SECTORS IN 2014 R\&D INVESTMENT (SOURCE: IRI 2015 SCOREBOARD)

\begin{tabular}{|c|c|c|c|}
\hline Rank & Sector & $\begin{array}{c}\text { Number of Companies } \\
\text { within the 1000 List }\end{array}$ & $\begin{array}{c}\text { Total R\&D 2014 } \\
\text { (€ millions) }\end{array}$ \\
\hline 1 & Pharmaceuticals \& Biotechnology & $102(10.20 \%)$ & $102,510.9(18.55 \%)$ \\
\hline 2 & Automotive \& Parts & $82(8.20 \%)$ & $92,044.3(16.65 \%)$ \\
\hline 3 & Technology Hardware \& Equipment & $144(14.40 \%)$ & $88,174.8(15.95 \%)$ \\
\hline 4 & Software \& Computer Service & $96(9.60 \%)$ & $56,755.2(10.27 \%)$ \\
\hline 5 & Electronic \& Electrical Equipment & $82(8.20 \%)$ & $40,738.5(7.37 \%)$ \\
\hline 6 & Industrial Engineering & $71(7.10 \%)$ & $19,638.0(3.55 \%)$ \\
\hline 7 & Aerospace \& Defense & $32(3.20 \%)$ & $19,458.4(3.52 \%)$ \\
\hline 8 & Chemicals & $60(6.00 \%)$ & $18,400.9(3.33 \%)$ \\
\hline 9 & General Industrials & $32(3.20 \%)$ & $15,430.3(2.79 \%)$ \\
\hline 10 & Leisure Goods & $25(2.50 \%)$ & $12,560.9(2.27 \%)$ \\
\hline
\end{tabular}

* 274 companies are in smaller sectors and are not included in the top 10 sectors.

\section{ANALYSIS OF THE CHINESE CORPORATIONS IN THE TOP 1000 LIST}

Examining the 81 Chinese corporations that achieved the top 1000 list, they can be grouped using the same sector categories and the results are presented in TABLE III. The author has some reservation on the IRI decision of placing the HUAWEI, the Chinese company with the highest R\&D investment, in the financial service sector. By combining HUAWEI with the Technology sector or the Electronic sector seems to make more sense. Nevertheless, the position of this company is still in consistent with the world trend, i.e., ICT is one off the top R\&D investment sector. The second group is the Construction \& Materials sector, which does reflect the recent two-three decades of growth in construction, infrastructure, high-speed railroads, and national transportation network projects in China. This high investment in $\mathrm{R} \& \mathrm{D}$ also enables these Chinese companies to compete in the world market such as the bidding for high-speed railroads outside China, and the construction of ports in the Indian Ocean countries, and the Panama Canal project.

Following the construction \& material sector are the Technology \& Hardware Equipment sector, the Automotive $\&$ Parts sector, and the Software\& Computer Services sector. This order may not be completely identical to the world ranking presented in TABLE III, but they are still in consistent with the world leading pack. The main difference lies in the 'Pharmaceuticals \& Biotechnology' sector which has been recognized world-wide as the top R\&D investment sector, while this sector in China is falling into the last few groups. According to the Chinese culture, traditional Chinese herbs are still considered as a more gentle treatment option, comparing to the western medicine. As pointed out in [2], national culture does correlate to the $\mathrm{R} \& \mathrm{D}$ investment. The low investment by the Chinese companies in the 'Pharmaceuticals \& Biotechnology' sector maybe best explained by the Chinese culture of using traditional herbs rather than the western approach of using synthetic medicine.

TABLE IV

81 CHINESE CORPORATES SECTOR RANKING BASED ON 2014 R\&D INVESTMENT

\begin{tabular}{|c|c|c|}
\hline Sector & $\begin{array}{l}\text { Chinese Corporates and } \\
\text { Corresponding } 1000 \text { Rank }\end{array}$ & $\begin{array}{l}\text { R\&D } 2014 \\
€ \text { millions }\end{array}$ \\
\hline Financial services & HUAWEI (15) & $5,441.2$ \\
\hline $\begin{array}{l}\text { Construction \& } \\
\text { Materials }\end{array}$ & $\begin{array}{l}\text { CHINA RAILWAY (91); CHINA RAILWAY CONSTRUCTION (102); CHINA STATE } \\
\text { CONSTRUCTION ENGINEERING (156); } \\
\text { CHINA COMMUNICATIONS CONSTRUCTION (237); } \\
\text { POWER CONSTRUCTION CORPORATION OF CHINA (396); CHINA NATIONAL } \\
\text { CHEMICAL ENGINEERING (456); SHANGHAI CONSTRUCTION (599); CHINA } \\
\text { NATIONAL MATERIALS (733); CHINA GEZHOUBA (744); SHANGHAI TUNNEL } \\
\text { ENGINEERING (877) }\end{array}$ & $\begin{array}{c}\text { Sub-Total: } \\
\mathbf{4 , 5 5 8 . 2}\end{array}$ \\
\hline $\begin{array}{c}\text { Technology Hardware } \\
\text { \& Equipment }\end{array}$ & $\begin{array}{l}\text { ZTE (83); LENOVO (128); GREAT WALL TECHNOLOGY (397); TPV TECHNOLOGY } \\
\text { (422); TCL COMMUNICATION TECHNOLOGY (480); TSINGHUA TONGFANG (510); } \\
\text { SINA (542); SEMICONDUCTOR MANUFACTURING (549); DATANG TELECOM } \\
\text { TECHNOLOGY (724); CHINA TELECOM (922); COOLPAD (983); }\end{array}$ & $\begin{array}{c}\text { Sub-Total: } \\
\mathbf{3 , 7 3 1 . 0}\end{array}$ \\
\hline $\begin{array}{l}\text { Automotive \& } \\
\text { Parts }\end{array}$ & $\begin{array}{l}\text { SAIC MOTOR (135); GREAT WALL MOTOR (292); ANHUI JIANGHUI AUTOMOBILE } \\
\text { (294); DONFENG MOTOR (321); CHONGING CHANGAN (381); GUANGZHOU } \\
\text { AUTOMOBILE (424); JIANGLING MOTORS (438); ZHENGZHOU YUTONG BUS (585); } \\
\text { HAIMA AUTOMOBILE GROUP (842); GEELY AUTOMOBILE (930); WEICHAI POWER } \\
\text { (953) }\end{array}$ & $\begin{array}{c}\text { Sub-Total: } \\
\mathbf{3 , 0 7 6 . 5}\end{array}$ \\
\hline
\end{tabular}


TABLE IV. 81 CHINESE CORPORATES SECTOR RANKING BASED ON 2014 R\&D INVESTMENT (continued)

\begin{tabular}{|c|c|c|}
\hline $\begin{array}{l}\text { Software \& Computer } \\
\text { Services }\end{array}$ & $\begin{array}{l}\text { BAIDU (131); TENCENT (132); QIHOO } 360 \text { TECH. (299); NETEASE.COM (493); } \\
\text { PERFECT WORLD (577); KINGSOFT (646); LESHI INTERNET INFORMATION \& } \\
\text { TECH. (728) }\end{array}$ & $\begin{array}{l}\text { Sub-Total: } \\
\mathbf{2 , 7 7 0 . 1}\end{array}$ \\
\hline $\begin{array}{l}\text { Oil \& Gas } \\
\text { Producers }\end{array}$ & PETROCHINA (65); CHINA PETROLEUM \& CHEMICALS (159); CNOOC (386) & $\begin{array}{c}\text { Sub-Total: } \\
\mathbf{2 , 7 6 3 . 7}\end{array}$ \\
\hline Industrial Engineering & $\begin{array}{l}\text { CRRC CHINA (169); SHANGHAI ELECTRIC (273); BEIQI FU TIAN VEHICLE (384); } \\
\text { DONGFANG ELECTRIC (554); SANY HEAVY INDUSTRY (565); CHINA } \\
\text { SHIPBUILDING (640); CHINA CSSC (763); SHANGHAI MECHANICAL \& } \\
\text { ELECTRICAL INDUSTRY (780) }\end{array}$ & $\begin{array}{l}\text { Sub-Total: } \\
\mathbf{1 , 9 5 5 . 8}\end{array}$ \\
\hline $\begin{array}{l}\text { Elecctronic \& } \\
\text { Electrical } \\
\text { Equipment }\end{array}$ & $\begin{array}{l}\text { BYD (248); BOE TECHNOLOGY GROUP )611); SHENZHEN O FILM TECH (692); } \\
\text { GOERTEK (751); AAC TECHNOLOGIES HOLDINGS (853); CHINA XD ELECTRIC } \\
\text { (939); YINGLI GREEN ENERGY (959) }\end{array}$ & $\begin{array}{c}\text { Sub-Total: } \\
\mathbf{1 , 0 2 9 . 0}\end{array}$ \\
\hline $\begin{array}{c}\text { General } \\
\text { Industrials }\end{array}$ & $\begin{array}{l}\text { METALLURGICAL OF CHINA (340); SHANGHAI ZHENHUA (764); CHINA } \\
\text { INTERNATIONAL MARINE CONTAINERS (779); KINGFA SCIENCE \& } \\
\text { TECHNOLOGY (889) }\end{array}$ & $\begin{array}{l}\text { Sub-Total: } \\
\mathbf{5 8 6 . 1}\end{array}$ \\
\hline Banks & CHINA MERCHANT BANK (210) & 521.5 \\
\hline $\begin{array}{c}\text { Industrial } \\
\text { Metals \& Mining }\end{array}$ & HBIS (398); GANSU JIU STEEL GROUP HONG XING IRON \& STEEL (518) & $\begin{array}{c}\text { Sub-Total: } \\
\text { 401.6 }\end{array}$ \\
\hline $\begin{array}{c}\text { Pharmaceuticals \& } \\
\text { Biotechnology }\end{array}$ & $\begin{array}{l}\text { SINO BIOPHARMACEUTICAL (714); FOSUN INTRNATIONAL (851); SHANGHAI } \\
\text { FOSUN PHARMACEUTICAL (948); ZHEJIANG HISUN PHARMACEUTICAL (968) }\end{array}$ & $\begin{array}{c}\text { Sub-Total: } \\
\text { 353.4 } \\
\end{array}$ \\
\hline Travel \& Leisure & CTRIP.COM INTERNATIONAL (326) & 312.5 \\
\hline Leisure Goods & $\begin{array}{l}\text { ZHEJIANG DAHUA TECHNOLOGY (746); SHANDA GAMES (861); TRULY } \\
\text { INTERNATIONAL ( } 887 \text { ) }\end{array}$ & $\begin{array}{c}\text { Sub-Total: } \\
278.9\end{array}$ \\
\hline Fix-Line Comm. & FIBERHOME TELEKOMMUNICATIONS TECHOLOGY (543) & 158.3 \\
\hline Miscellenous & $\begin{array}{l}\text { YUE YUEN INDUSTRIAL (580); AVICHINA INDUSTRY (623); MINDRAY MEDICAL } \\
\text { (633); SINOPEC ENG. (651); ZHEJIANG LONGSHENG (957) }\end{array}$ & $\begin{array}{l}\text { Sub-Total: } \\
\mathbf{6 1 1 . 9}\end{array}$ \\
\hline
\end{tabular}

\section{SUMMARY}

In this paper, we analyzed the EU Commission's publication on world companies' investment in R\&D. Specifically, we extract these Chinese companies that made the top 1000 list and compare them with companies outside China. Overall, those top Chinese corporations are in line with the rest of the world, with the exception of the Pharmaceuticals \& Biotechnology category. Our next task is to analyze the profit margin, the percentage of $R \& D$ with respect to the total revenue over a period of time. The objective is to verify whether Chinese corporations will still endorse the idea of continuously increasing the $R \& D$ investment, regardless of the short term disruption in the world market.

\section{REFERENCES}

[1] European Commission: Economics of Industrial Research \& Innovation, EU R\&D Scoreboard: the 2015 EU Industrial R\&D Investment Scoreboard, 2015, Luxembourg, Publication Office of the European Union, ISBN: 978-92-79-53020-3, 2015.

[2] Nikos C. Varsakelis, "The Impact of Patent Protection, Economy Openness and National Culture on R\&D Investment: A Cross-Country Empirical Investigation", Research Policy, Vol. 30, no.7, pp. 1059-1068, 2001. 